EREM 73/3

Journal of Environmental Research, Engineering and Management Vol. 73 / No. 3 / 2017 pp. $54-68$ DOI 10.5755/j01.erem.73.3.13985 (c) Kaunas University of Technology
Radiation Treatment of Skim Serum Wastewater from Natural Rubber Latex Centrifuging Units
Accepted after revision 2017/09

\title{
Radiation Treatment of \\ Skim Serum Wastewater \\ from Natural Rubber Latex \\ Centrifuging Units
}

\section{Vimalamma T Abraham}

Department of Chemistry, St. Stephen's College, Uzhavoor, Kerala, India

\section{G. Madhu}

School of Engineering, Cochin University of Science and Technology, Cochin, India

\section{N. Radhakrishnan Nair, John Britto}

Rubber Research Institute of India, Kottayam, Kerala, India

Corresponding author: profmadhugopal@gmail.com

G. Madhu, Cochin University of Science and Technology, School of Engineering, Cochin, India

Tel: 91-484-2862180. Fax: 91-484-2577405

The skim serum wastewater generated during the centrifuging of natural rubber latex is highly polluting in nature. The raw wastewater and its anaerobically treated form were subjected to the gamma irradiation treatment. Different combinations of Fenton's reagent and different doses of gamma radiations were also applied. The effectiveness of treatment was assessed in terms of $\mathrm{pH}$, turbidity, chemical oxygen demand, biochemical oxygen demand, total Kjeldahl nitrogen, ammoniacal nitrogen, total solids, dissolved solids and sulphide. Changes in the concentrations of biochemical constituents and enumeration of total bacterial population were also used to assess the treatment efficiency. Anaerobically treated effluent can be more effectively treated using gamma radiation and Fenton's reagent. Most of the biochemical constituents and bacterial populations were completely removed from the anaerobically treated effluent by this method of treatment.

Keywords: gamma ray, irradiation, rubber latex centrifuging, skim serum wastewater, Fenton's reagent. 


\section{Introduction}

Natural rubber (NR) latex is obtained from the bark of the rubber tree (Hevea brasiliensis) by tapping. Structurally, NR is a cis-1, 4-polyisoprene $\left(\mathrm{C}_{5} \mathrm{H}_{8}\right)$. NR latex is a colloidal system comprised of rubber globules dispersed in an aqueous serum. Processing of fresh latex is essential to maintain its quality. Field latex (preserved by adding ammonia, which inhibits bacterial growth) is unsuitable for most latex applications as its rubber content is low. For most product manufacture, latex of minimum $60 \%$ dry rubber content is essential. One of the important methods for the concentration of preserved field latex (contains $30 \%$ to $33 \%$ of rubber) is centrifuging using high speed centrifuges to obtain $60 \%$ rubber and skim latex containing $4-6 \%$ of rubber. Skim latex, which contains about $0.8 \%$ of ammonia, is coagulated with $98 \%$ sulphuric acid to recover rubber. The skim serum produced after coagulation of rubber contains a significant amount of non-rubbers, which include proteins, sugars, lipids, carotenoids and organic and inorganic salts originating from latex and a very small amount of uncoagulated latex (Kumaran, 1987). These constituents are excellent substrates for the proliferation of micro-organisms generating high biochemical oxygen demand (BOD) and objectionable odour and needs proper treatment.

Radiation treatment is emerging as an environment friendly technology for recycling wastewater. Gamma rays are used for treating industrial effluents that are very hard to be treated by conventional methods. Advantages of the method mainly are that it does not create by-products, elimination of the hazard of overdosing of oxidising agents and a high process rate and efficiency. Through primary and secondary products of water radiolysis, the ionising radiation causes the decomposition of organic compounds contained in water. In pilot plant and industrial installations, the advanced oxidation process has been used in the treatment of drinking water and industrial wastewater (Kos \& Perkowski, 2003, Rice, 1997). Much interest is evinced on the potential of using gamma radiation in the treatment of municipal and industrial wastewater and drinking water (Waite et al., 1992). Radiation combined with biological processes has been used in the treatment of wastewater originating from production of antibiotics and metallurgy where large quantities of detergents and fats are used in the production process (White, 1978). Investigations on the effect of gamma radiation on poliovirus infectivity seeded in sludge samples, elimination of the endocrine-disrupting activity of 17 beta-estradiol, reduction in the population of coliphage, total coliforms and total flora present in raw sewage and secondary effluent, comparison of the toxicity responses of irradiated wastewater effluent samples to chlorinated municipal wastewater effluent samples, and treatment of several animal viruses found in effluent from an animal disease laboratory have been reported (Kimura et al., 2004, Farooq et al., 1993, Getoff, 1996, John \& Blatchley, 1999, Thomas et al., 1982). Gamma rays are used for the treatment of sewage (Jung et al., 2002, 2004, Meeroff et al., 2004), pulp mill bleach effluents (Wang et al., 1994), surfactant and petroleum product wastewater, dyeing complex wastewater and paper mill effluents (Pikaey, 2001) and for the disinfection of wastewater (Basfar \& Rehim, 2002). The main advantage of the gamma radiation treatment is its ability to inactivate pathogens with a high degree of reliability associated with the process in a clean and efficient manner ensuring easy operation and maintenance of the plant.

Since there is a growing interest in advanced oxidation processes like radiation technology to treat wastewater, a study was initiated to apply this method in combination with chemical oxidants like Fenton's reagent to treat the skim serum wastewater from a centrifuging rubber latex factory. The objective of the present study was to investigate the impact of gamma irradiation on the treatment of raw and anaerobically treated skim serum effluent. The combined effect of gamma radiation and Fenton's reagent on these effluents was also studied. The impact of radiation treatment on the chemical oxygen demand (COD), biochemical oxygen demand (BOD), total Kjeldahl nitrogen (TKN), ammoniacal nitrogen (AN), turbidity, sulphides 
and phosphates and biochemical constituents like soluble protein, free amino acids, phenol, total sugar, reducing and non-reducing sugars and population of total bacteria were also part of the study.

\section{Material and methods}

Natural rubber skim serum effluent samples were collected from a centrifuge latex concentration unit in Kottayam district of Central Kerala, India. To obtain an anaerobically treated sample for the study, the effluent was subjected to anaerobic treatment in a bench-scale upflow anaerobic sludge blanket (UASB) reactor. Raw and treated samples were analysed for various parameters as per standard methods (APHA et al., 1992) and the results of analysis are given in Table 1.

\section{Table 1}

Characteristics of raw and anaerobically treated effluent

\begin{tabular}{c|c|c}
\hline Parameter & Raw effluent & $\begin{array}{c}\text { Anaerobically } \\
\text { treated effluent }\end{array}$ \\
\hline 1 & 2 & 3 \\
\hline pH & 3.6 & 8.5 \\
\hline Turbidity ( NTU) & 350 & 107 \\
\hline COD & 36,400 & 4,508 \\
\hline BOD & 27,300 & 815 \\
\hline TKN & 7,000 & 4,480 \\
\hline AN & 5,000 & 3,500 \\
\hline Total solids (TS) & 60,000 & 32,418 \\
\hline Dissolved solids (DS) & 58,000 & 30,554 \\
\hline Sulphide & 14.00 & 235 \\
\hline Phosphate & 2,600 & 1,525 \\
\hline
\end{tabular}

All units except $\mathrm{pH}$ and turbidity are expressed in $\mathrm{mg} / \mathrm{L}$

Gamma irradiation of effluent samples was done at the Radiation Vulcanization of Natural Rubber Latex (RVNRL) Plant of Rubber Research Institute of India (RRII), Kerala, India using a laboratory scale Co-60 gamma source.
The effects of the following factors were investigated: the dose of radiation viz. $0.5 \mathrm{kGy}$ to $100 \mathrm{kGy}, \mathrm{pH}$ of the effluent, addition of various chemicals like ferrous sulphate, Fenton's reagent and pollutant concentration of the effluent. After irradiation, the samples were analysed for various parameters to evaluate the extent of treatment. Biochemical analysis of the wastewater for concentration of total sugars (Scott Jr. \& Melvin, 1953), reducing sugars (Nelson, 1944), total and soluble proteins (Lowry et al., 1951), phenols (Swain \& Hills, 1959), and free amino acids (Moore \& Stein, 1948) were carried out as per standard analytical techniques using a UV-visible recording spectrophotometer UV-240. The standard serial dilution plate technique of Pramer and Schmidt (1965) was employed for the enumeration of microbiological population.

\section{Results and discussion}

\section{Effect of irradiation dose on pollutant removal Effect on COD and BOD removal}

The effect of the exposure rate on the treatment of the raw effluent was investigated within the range of 0.5 kGy $(0.05 \mathrm{Mrad})$ to $100 \mathrm{kGy}(10 \mathrm{Mrad})$. The COD removal efficiency was found to increase as the dose of gamma radiation increased from 0.5 to $2.5 \mathrm{kGy}$. The maximum COD removal efficiency of $24 \%$ was achieved at $2.5 \mathrm{kGy}$; thereafter, it showed fluctuations as shown in Figure 1.

A further increase of the dose up to $100 \mathrm{kGy}$ had practically little effect on COD removal. For BOD removal, the same trend was noticed. A maximum BOD removal efficiency of $60-65 \%$ was obtained for the radiation dose of 2.5 to $3 \mathrm{kGy}$.

\section{Effect on $\mathrm{pH}$}

There was no significant change in $\mathrm{pH}$ after irradiating with gamma rays as is evident from Figure 2. A very slight increase in $\mathrm{pH}$ was observed for almost all irradiation doses, and this may be due to the reactions of hydroxyl radicals generated during radiolysis.

\section{Effect on TKN, AN, TS, DS and turbidity removal}

Gamma radiation showed only $23 \%$ and 28\% removal of TKN and AN, respectively, in the range of 1 to 2.75 kGy (Figure 3). 
Fig. 1

Percentage removal of $\mathrm{COD}$ and $\mathrm{BOD}$ vs radiation dose

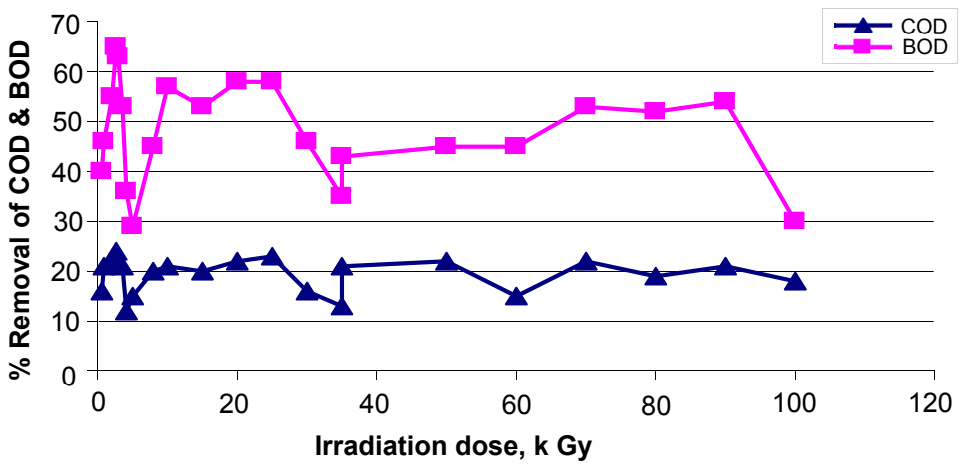

Fig. 2

Effect of irradiation on $\mathrm{pH}$

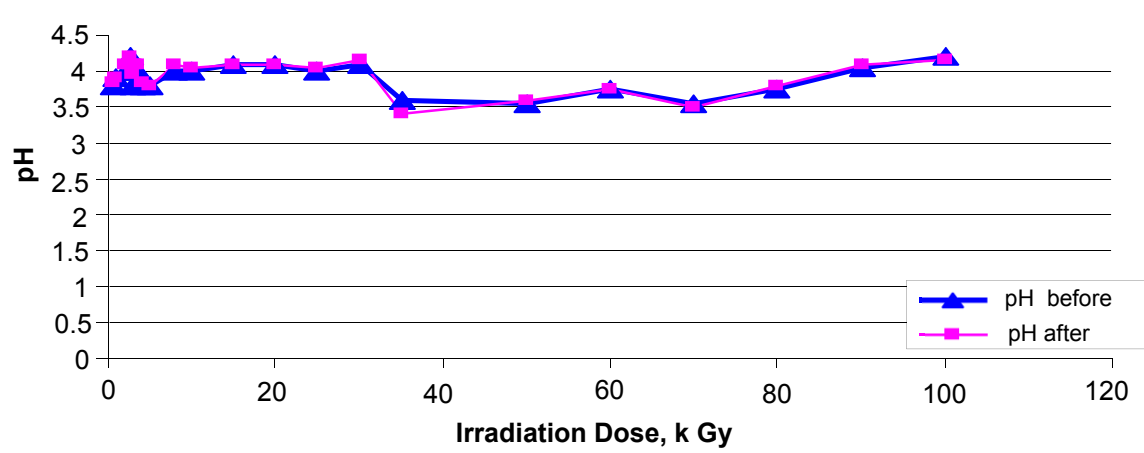

Fig. 3

Effect of the radiation dose on TKN and AN removal

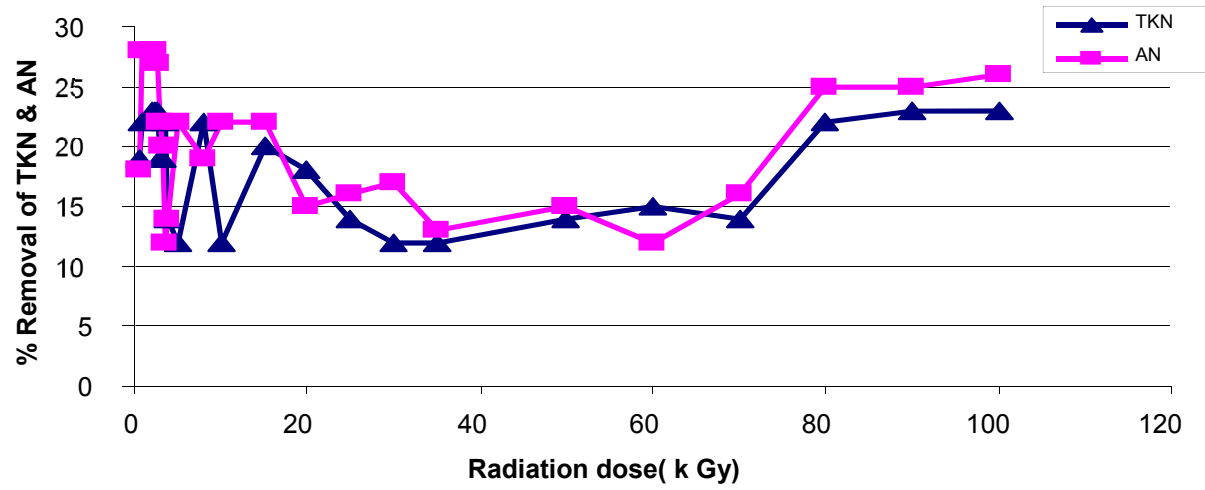


Fig. 4

Effect of the radiation dose on TS, DS and turbidity removal

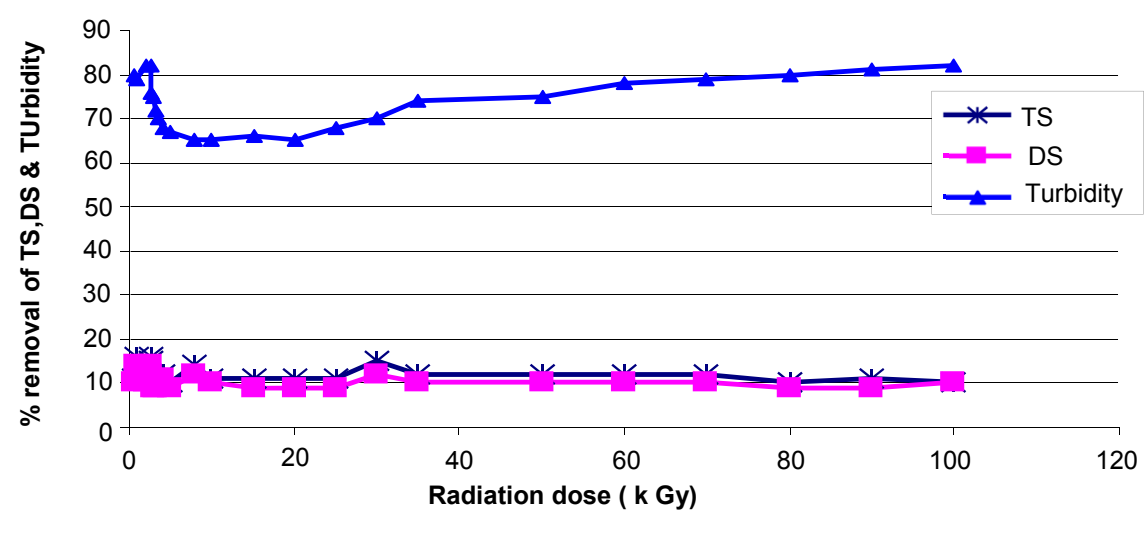

Maximum removal of TS and DS were 16\% and 14\%, respectively, for the doses in the range 1-2.75 kGy. However, the turbidity removal was in the range of 80 to $82 \%$. Maximum turbidity removal was obtained for an irradiation dose of 0.5 to $2.5 \mathrm{kGy}$ and 70 to $100 \mathrm{kGy}$ (Figure 4).

It was observed that after gamma irradiation the effluent became very clear and good settling was observed even at a radiation dose as low as $0.5 \mathrm{kGy}$.

From the percentage removal of pollutants obtained, a dose of $2.5 \mathrm{kGy}$ was taken as the optimum dose of irradiation to treat skim serum effluent. This may be attributed to the fact that a radiation dose of 2-3 kGy can effectively decompose the contaminants in the wastewater (Gautam et al., 2005).

\section{Factors influencing the efficiency of radiation treatment}

\section{Influence of $\mathrm{pH}$ and gamma radiation on COD and} BOD removal

To study the effect of $\mathrm{pH}$ and gamma radiation on the removal of pollutants, the $\mathrm{pH}$ of the effluent was adjusted to $3,4,5,6,7,8$ and 9 before subjecting to gamma radiation at a dose of $2.5 \mathrm{kGy}$. The effect of $\mathrm{pH}$ on percentage reduction of $\mathrm{COD}$ and $\mathrm{BOD}$ is illustrated in Figure 5. A reduction in the percentage removal of

Fig. 5

Effect of pH on COD and BOD removal efficiency

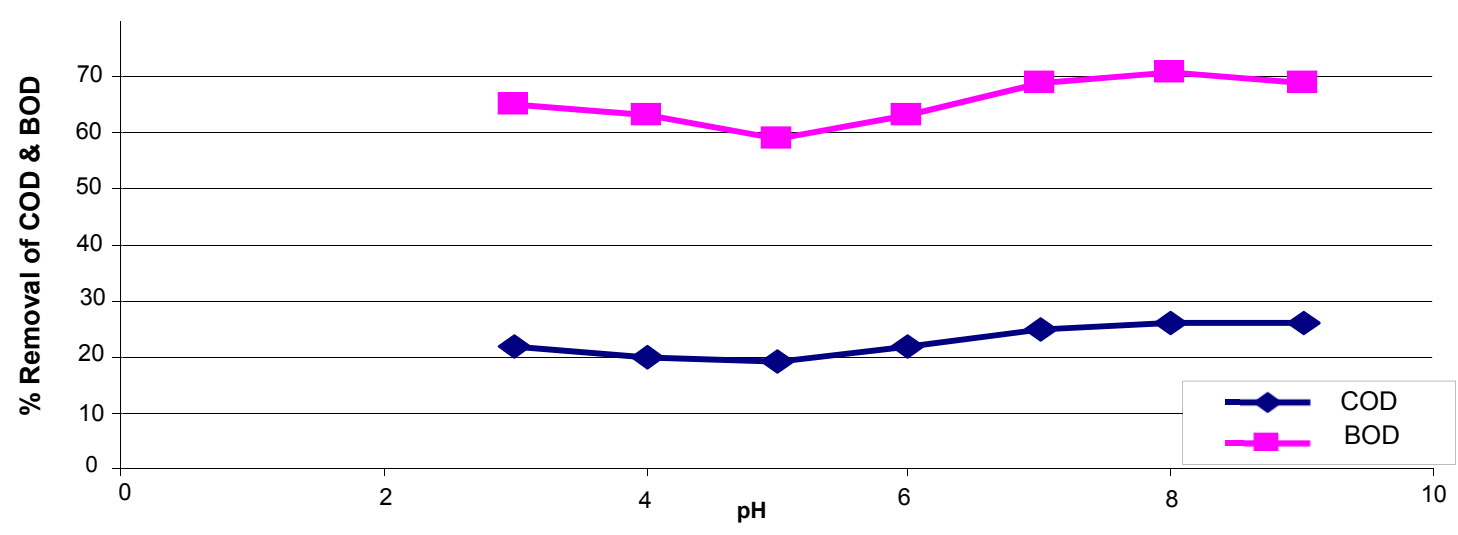


COD and BOD was observed as the $\mathrm{pH}$ of the effluent increased from 3 to 5 and then showed a steady increase as $\mathrm{pH}$ changed from 5 to 7 . The values remained almost constant after $\mathrm{pH} 7$. Therefore, $\mathrm{pH}$ between 7 and 8 could be taken as the optimum.

In the advanced oxidation process, $\mathrm{OH}$ has got a predominant role in the decomposition of organic molecules. Perkowski and Kos (2003) observed the same trend of maximum decomposition of organic contaminants at neutral or slightly alkaline $\mathrm{pH}$ in the decolouration of model dye house wastewater using the advanced oxidation process.

\section{Influence of various reagents}

The objective of this study was to ascertain the individual and combined effect of various reagents added to the wastewater before subjecting it to gamma irradiation. The following reagents were added to the raw effluent: (a) $200 \mathrm{mg} / \mathrm{L}$ of iron, (b) $5 \mathrm{~mL} / \mathrm{L} \mathrm{H}_{2} \mathrm{O}_{2}$, (c) $200 \mathrm{mg} / \mathrm{L}$ of iron and $5 \mathrm{~mL} / \mathrm{L} \mathrm{H}_{2} \mathrm{O}_{2}$ along with a control without any reagent, subjected to gamma radiation having a dose of $2.5 \mathrm{kGy}$ and analysed for various parameters. The results are given in Table 2 .

A slight increase in $\mathrm{pH}$ occurred when the effluent was irradiated alone and a decrease in $\mathrm{pH}$ occurred when the effluent was irradiated either in the presence of iron or iron and hydrogen peroxide. When hydrogen peroxide alone was added, there was no change in $\mathrm{pH}$ after irradiation.

Maximum reduction of $\mathrm{COD}$ and BOD was obtained when the raw effluent was irradiated in the presence of $200 \mathrm{mg} / \mathrm{L}$ of iron $+5 \mathrm{~mL} / \mathrm{L}$ of $\mathrm{H}_{2} \mathrm{O}_{2}$ compared with individual applications of the reagents. Radiation in the presence of $\mathrm{H}_{2} \mathrm{O}_{2}$ alone showed negative values in the removal of turbidity, and the COD and BOD reduction were also comparatively low. In the absence of iron, formation of hydroxyl radical was negligible, and this should have negatively affected the treatment efficiency.

\section{Effect of gamma radiation at various concentration of iron in Fenton's reagent $\left(\mathrm{FeSO}_{4}+\mathrm{H}_{2} \mathrm{O}_{2}\right)$}

The effect of gamma irradiation in the presence of Fenton's reagent to remove pollutants was studied. Oxidation by Fenton's reagent is catalysed by $\mathrm{Fe}^{+2}$. Experiments were conducted to ascertain the effect of $\mathrm{Fe}^{+2}$ and to find out the optimum dosage of $\mathrm{Fe}^{+2}$ for the degradation of pollutants in the wastewater. The effluent sample was subjected to gamma radiation having a dose of $2.5 \mathrm{kGy}$ in the presence of Fenton's reagent having different concentrations of iron viz., $20 \mathrm{mg} / \mathrm{L}$, $80 \mathrm{mg} / \mathrm{L}, 140 \mathrm{mg} / \mathrm{L}, 200 \mathrm{mg} / \mathrm{L}, 300 \mathrm{mg} / \mathrm{L}, 400 \mathrm{mg} / \mathrm{L}$ along with a fixed dose of $\mathrm{H}_{2} \mathrm{O}_{2}\left(5 \mathrm{~mL} / \mathrm{L}\right.$ of $\left.30 \% \mathrm{H}_{2} \mathrm{O}_{2}\right)$.

The addition of ferrous sulphate and hydrogen peroxide resulted in the reduction of $\mathrm{pH}$ since the ferrous sulphate catalyst typically contains residual $\mathrm{H}_{2} \mathrm{SO}_{4}$. When the effluent was subjected to gamma radiation in the presence of Fenton's reagent, $\mathrm{pH}$ was found to decrease in all the cases as evident from Table 3.

This drop in $\mathrm{pH}$ could be attributed to the fragmentation of the organic molecules present in wastewater

\section{Table 2}

Influence of gamma radiation in presence of various reagents to remove pollutants

\begin{tabular}{c|c|c|c|c|c}
\hline \multirow{2}{*}{ RE and the following reagents } & \multicolumn{2}{|c|}{$\mathrm{pH}$} & \multicolumn{3}{|c}{ Percentage removal } \\
\cline { 2 - 6 } & Before & After & Turbidity (NTU) & COD & 5 \\
\hline 1 & 2 & 3 & 4 & 23 & 64 \\
\hline $\mathrm{Y}$ & 4.15 & 4.20 & 45 & 29 & 69 \\
\hline $\mathrm{Y}+200 \mathrm{mg} / \mathrm{L}$ of Fe & 3.15 & 3.10 & 55 & 25 & 63 \\
\hline $\mathrm{Y}+5 \mathrm{~mL} / \mathrm{L} \mathrm{H} \mathrm{H}_{2}$ & 4.15 & 4.15 & -53 & 36 & 73 \\
\hline
\end{tabular}


Table 3

Effect of gamma radiation at various concentration of iron in Fenton's reagent

\begin{tabular}{|c|c|c|c|c|c|c|}
\hline \multirow{2}{*}{$\begin{array}{l}\mathrm{RE}+\mathrm{H}_{2} \mathrm{O}_{2}(5 \mathrm{~mL} / \mathrm{L}+\mathrm{Fe} \\
\text { (conc. given below) }\end{array}$} & \multicolumn{2}{|c|}{$\mathrm{pH}$} & \multicolumn{4}{|c|}{ Percent removal } \\
\hline & Before y & After $Y$ & Turbidity (NTU) & COD & BOD & Phosphate \\
\hline 1 & 2 & 3 & 4 & 5 & 6 & 7 \\
\hline$R E+\gamma$ (without any reagents) & 4.00 & 4.05 & 45 & 23 & 63 & 12 \\
\hline $20 \mathrm{mg} / \mathrm{L}$ iron & 3.90 & 3.80 & 87 & 29 & 70 & 17 \\
\hline $80 \mathrm{mg} / \mathrm{L}$ iron & 3.50 & 3.40 & 90 & 30 & 72 & 29 \\
\hline $140 \mathrm{mg} / \mathrm{L}$ iron & 3.25 & 3.15 & 92 & 31 & 74 & 35 \\
\hline 200 mg/L iron & 2.90 & 2.80 & 95 & 33 & 75 & 44 \\
\hline 300 mg/L iron & 2.75 & 2.70 & 95 & 33 & 74 & 46 \\
\hline $400 \mathrm{mg} / \mathrm{L}$ iron & 2.25 & 2.20 & 95 & 31 & 73 & 54 \\
\hline
\end{tabular}

into organic acids as the reaction progresses. The effect of iron concentration in Fenton's reagent on the removal of turbidity showed that maximum turbidity removed was $95 \%$ when the concentration of iron was $200 \mathrm{mg} / \mathrm{L}$ to $400 \mathrm{mg} / \mathrm{L}$. There was a steady increase in the removal of turbidity as the concentration of iron increased from $80 \mathrm{mg} / \mathrm{L}$ to $200 \mathrm{mg} / \mathrm{L}$. Good sedimentation of coagulated particles was observed after irradiation and the wastewater became very clear.

The optimum dose of iron concentration in Fenton's reagent was assessed in terms of its efficiency to remove COD and BOD. It was observed that on incremental increase of $\mathrm{Fe}^{+2}$ dosages, an increase in the reduction of COD and BOD values was observed as is evident from Table 3 and maximum percentage removal of COD and BOD was obtained at a concentration of $200 \mathrm{mg} / \mathrm{L}$ of iron. At this concentration of iron in Fenton's reagent, $33 \%$ of COD and $75 \%$ of BOD were removed. A further increase in the concentration of iron (200 mg/L to $400 \mathrm{mg} / \mathrm{L}$ ) had only a marginal impact. A higher concentration of iron catalyst results in an increased rate of generation of $\mathrm{OH}$ radical, which in turn limits the reaction rates with Fenton's reagent. A constant ratio of Fe to substrate above the minimal threshold level produced the desired end products. The ratio of iron to substrate ay affect the distribution of reaction products; and a supplemental aliquot of $\mathrm{Fe}$, which saturates the chelating properties in the wastewater, makes available unsequestered iron to catalyse the formation of hydroxyl radicals (Walling, 1975). Since the pollution load is very high in skim serum wastewater, a concentration of $200 \mathrm{mg} / \mathrm{L}$ of iron could be taken as the optimum concentration in Fenton's reagent to treat this effluent.

In the case of phosphate, the removal efficiency increased as the concentration of iron increased from $20 \mathrm{mg} / \mathrm{L}$ to $400 \mathrm{mg} / \mathrm{L}$. Without Fenton's reagent, phosphate removal efficiency was only $12 \%$ and it increased from $17 \%$ to $54 \%$ when iron concentration in Fenton's reagent increased from $20 \mathrm{mg} / \mathrm{L}$ to $400 \mathrm{mg} / \mathrm{L}$. As the concentration of iron increased, it combined with the phosphate and was removed as iron phosphate.

\section{Effect of gamma radiation at various concentration of $\mathrm{H}_{2} \mathrm{O}_{2}$ in Fenton's reagent}

The effect of different concentrations of hydrogen peroxide on raw effluent in the presence of $200 \mathrm{mg} / \mathrm{L}$ of iron and gamma ray was investigated by adding $5 \mathrm{~mL} / \mathrm{L}$ to $30 \mathrm{~mL} / \mathrm{L}$ of $30 \% \mathrm{H}_{2} \mathrm{O}_{2}$ to the effluent and irradiating it with a dose of $2.5 \mathrm{kGy}$. The optimum dose of $\mathrm{H}_{2} \mathrm{O}_{2}$ was $10 \mathrm{~mL} / \mathrm{L}$ in the presence of $200 \mathrm{mg} / \mathrm{L}$ of iron since the highest removal of turbidity, COD, BOD and phosphate took place at this dose (Table 4).

A high ratio of $\mathrm{Fe}^{+2}$ and $\mathrm{H}_{2} \mathrm{O}_{2}$ was needed for chain initiation as shown in Eq. 1 (Rivas et al., 2001). 
Table 4

Effect of gamma radiation at different concentrations of $\mathrm{H}_{2} \mathrm{O}_{2}$ in Fenton's reagent

\begin{tabular}{|c|c|c|c|c|c|c|}
\hline \multirow{2}{*}{$\begin{array}{c}\mathrm{RE}+\underset{ }{200 \mathrm{mg} / \mathrm{L} \text { of } \mathrm{Fe}+\gamma}+\mathrm{H}_{2} \mathrm{O}_{2} \\
\quad \text { (Conc. given below) }\end{array}$} & \multicolumn{2}{|c|}{$\mathrm{pH}$} & \multicolumn{4}{|c|}{ Percentage removal } \\
\hline & Before $y$ & After $Y$ & Turbidity (NTU) & COD & BOD & Phosphate \\
\hline 1 & 2 & 3 & 4 & 5 & 6 & 7 \\
\hline $5 \mathrm{~mL} / \mathrm{L}$ & 2.75 & 2.8 & 75 & 33 & 71 & 43 \\
\hline $10 \mathrm{~mL} / \mathrm{L}$ & 2.70 & 2.8 & 82 & 35 & 77 & 46 \\
\hline $20 \mathrm{~mL} / \mathrm{L}$ & 2.70 & 2.8 & 66 & 35 & 75 & 5 \\
\hline $30 \mathrm{~mL} / \mathrm{L}$ & 2.25 & 2.3 & 40 & 30 & 75 & 2 \\
\hline
\end{tabular}

$$
\begin{aligned}
& \mathrm{Fe}^{+2}+\mathrm{H}_{2} \mathrm{O}_{2} \rightarrow \mathrm{Fe}^{+3}+\mathrm{OH}^{*}+\mathrm{OH} \\
& \mathrm{K}_{1}=70 \mathrm{~m}^{-1} \mathrm{~S}^{-1} \text { (chain initiation) }
\end{aligned}
$$

At low concentrations of $\mathrm{H}_{2} \mathrm{O}_{2}$, the radical chain reactions are quickly terminated since $\mathrm{OH}$ radicals produced mainly react with the ferrous iron and not with hydrogen peroxide (Buxton et al., 1988).

$$
\begin{aligned}
& \mathrm{OH}^{*}+\mathrm{Fe}^{+2} \rightarrow \mathrm{OH}+\mathrm{Fe}^{+3} \\
& \mathrm{~K}_{2}=3.2 \times 10^{y} \mathrm{~m}^{-1} \mathrm{~s}^{-1} \text { (chain termination) }
\end{aligned}
$$

Excess of $\mathrm{H}_{2} \mathrm{O}_{2}$ reacts with $\mathrm{OH}^{*}$, thus scavenging hydroxyl radicals by $\mathrm{H}_{2} \mathrm{O}_{2}$ and consequently reducing the efficiency of treatment as shown in Eq. 3. The oxidation rate seems to be negatively affected by the increase of $\mathrm{H}_{2} \mathrm{O}_{2}$ concentration.

$$
\mathrm{OH}^{*}+\mathrm{H}_{2} \mathrm{O}_{2} \rightarrow \mathrm{H}_{2} \mathrm{O}+\mathrm{HO}_{2}
$$

The higher percentage degradation efficiency is that hydroxyl radicals can oxidise organic pollutants by abstraction of hydrogen producing organic radicals which are highly reactive and can be further oxidised (Walling and Kato, 1971).

$$
\mathrm{RH}+{ }^{*} \mathrm{OH} \rightarrow \mathrm{H}_{2} \mathrm{O}+\mathrm{R}^{*}
$$

A higher concentration of $\mathrm{H}_{2} \mathrm{O}_{2}$ reacts with the highly potent $\mathrm{OH}^{*}$ radicals to produce perhydroxyl radical $\mathrm{OH}_{2}$, which has low oxidation potential than $\mathrm{OH}^{*}$ radical.

As the concentration of $\mathrm{H}_{2} \mathrm{O}_{2}$ increased, a sudden fall of phosphate removal took place (from 46 to 5 and $2 \%$ for $10 \mathrm{~mL} / \mathrm{L}$ to $20 \mathrm{~mL} / \mathrm{L}$ and $30 \mathrm{~mL} / \mathrm{L}$, respectively). This might be due to the interference caused by the excess perhydroxyl radical $\mathrm{OH}_{2}$ produced by the addition of a high amount of $\mathrm{H}_{2} \mathrm{O}_{2}$ during the formation of iron phosphate. Formation of a large amount of froth was observed when the concentration of hydrogen peroxide increased from $10 \mathrm{~mL} / \mathrm{L}$ to $30 \mathrm{~mL} / \mathrm{L}$ due to the evolution of gases like $\mathrm{CO}_{2}, \mathrm{H}_{2}$ and $\mathrm{O}_{2}$.

From these studies, it was concluded that the optimum doses of iron and hydrogen peroxide needed in Fenton's reagent to treat skim serum effluent were $200 \mathrm{mg} / \mathrm{L}$ and $10 \mathrm{~mL} / \mathrm{L}$, respectively.

\section{Effect of gamma radiation on pollutant removal at different concentration levels of wastewater}

Raw effluent of different concentrations like 100\%, $75 \%, 50 \%$ and $25 \%$ was prepared by diluting raw effluent with distilled water, and $\mathrm{pH}$ was adjusted to 4 and placed in a gamma chamber for gamma radiation having a dose of $2.5 \mathrm{kGy}$. The effect of gamma radiation on different concentrations of effluent was then analysed in terms of COD, BOD and phosphate removal.

The highest COD, BOD and phosphate removal were obtained for undiluted effluent. When the concentration of effluent decreased from $100 \%$ to $25 \%$, COD removal 
Fig. 6

Percentage removal of $\mathrm{COD}, \mathrm{BOD}$ and $\mathrm{PO}_{4}$

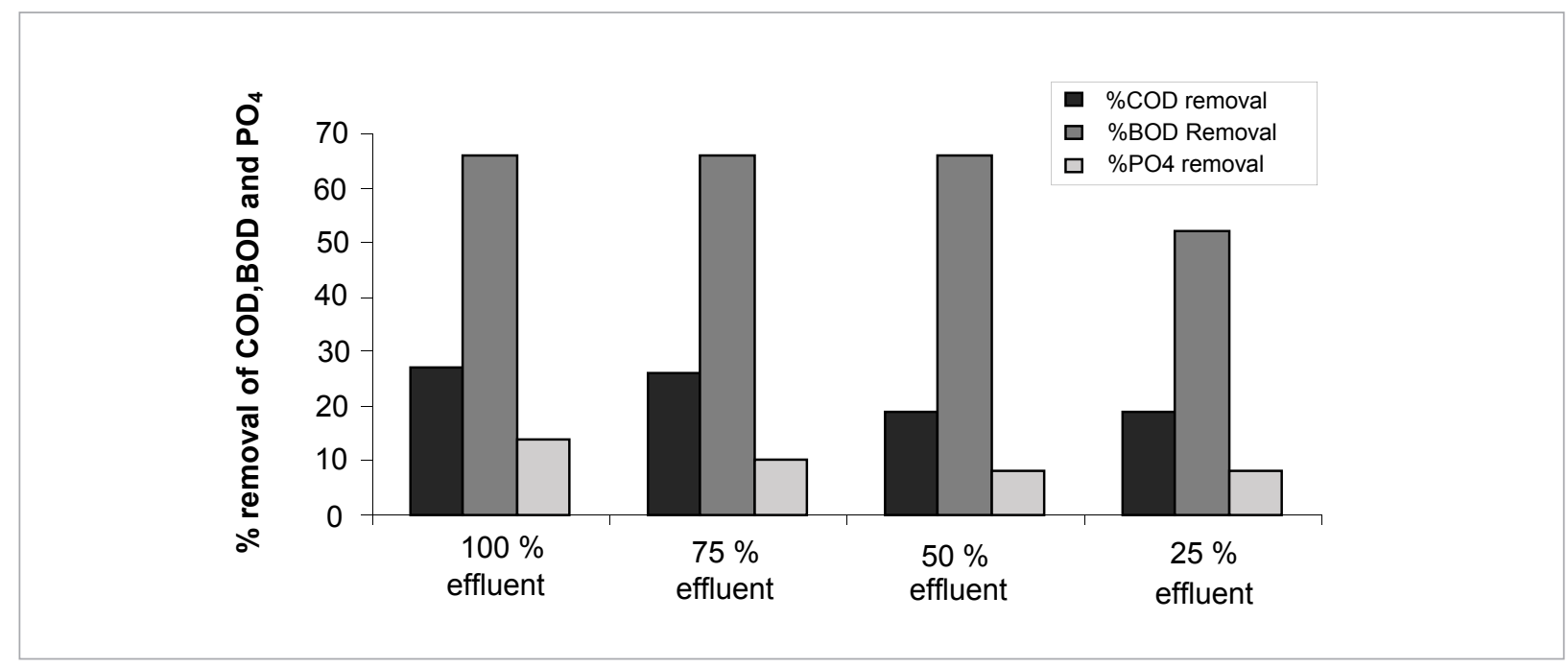

decreased from $27 \%$ to $19 \%$. However, BOD removal was $66 \%$ for dilution up to $50 \%$ effluent concentration, which declined to $52 \%$ for the $25 \%$ effluent concentration (Figure 6). In the case of phosphate, there was a steady decrease from $14 \%$ to $8 \%$ removal for the concentration change from $100 \%$ to $25 \%$. As dilution increases, the effective number of ions per $\mathrm{mL}$ that can be degraded by gamma radiation also decreases.

\section{Effect of gamma radiation and Fenton's reagent on anaerobically treated effluent (ATE)}

\section{Effect of gamma radiation and various reagents on ATE}

When ATE effluent was subjected to gamma irradiation of $2.5 \mathrm{kGy}$ without Fenton's reagent, $55 \%$ of turbidity, $29 \%$ of COD, $45 \%$ of BOD and $27 \%$ of sulphide were removed. However, when treated with Fenton's reagent alone (without gamma irradiation), 100\% of turbidity, $35 \%$ of COD, $59 \%$ of BOD and $89 \%$ of sulphide were removed. This shows that Fenton's reagent has good capability to remove sulphide and turbidity. Compared with raw wastewater, anaerobically treated effluent showed higher removal efficiency of pollutants while subjected to gamma radiation in the presence of Fenton's reagent (Table 5). In the anaerobic reaction, organic molecules are degraded by hydrolysis, fermentation and methanogenesis into simple monomers, acetate, hydrogen, methane and carbon dioxide (Metcalf \& Eddy, Inc., 2003), and this enhances the removal of $\mathrm{COD}$ and BOD compared with raw effluent.

As the concentration of iron in Fenton's reagent increased from $20 \mathrm{mg} / \mathrm{L}$ to $200 \mathrm{mg} / \mathrm{L}$, percentage removal efficiencies of COD increased from 41 to 77, BOD from 57 to 96 , sulphide from 52 to 95 and TKN from 16 to 19. The values remained almost constant for further increase in the concentration of iron to $400 \mathrm{mg} / \mathrm{L}$. However, its effect on AN was not so prominent. In all treatments where Fenton's reagent was used, 100\% removal of sulphide could be achieved.

\section{Effect of pH and Fenton's reagent on radiation treatment of anaerobically treated effluent}

To study the effect of $\mathrm{pH}$ and gamma radiation in the presence of Fenton's reagent on ATE, pH of the ATE was adjusted to 2.5, 3, 5, 7 and 8. To each of these sets, $5 \mathrm{~mL} / \mathrm{L}$ of $\mathrm{H}_{2} \mathrm{O}_{2}$ and $200 \mathrm{mg} / \mathrm{L}$ of iron were added and irradiated with $2.5 \mathrm{kGy}$. From Table 6, it is evident that $97 \%$ of turbidity, $72 \%$ of COD, $88 \%$ of BOD and $100 \%$ of sulphides were removed at $\mathrm{pH} 3$. This was the maximum reduction of pollutants obtained when anaerobically treated effluent was subjected to gamma irradiation in the presence of Fenton's reagent at various $\mathrm{pH}$. 


\section{Table 5}

Effect of gamma radiation and various reagents on ATE

\begin{tabular}{|c|c|c|c|c|c|c|c|c|}
\hline \multirow[b]{2}{*}{ Reagent type ATE } & \multicolumn{2}{|c|}{$\mathrm{pH}$} & \multicolumn{6}{|c|}{ Percentage removal } \\
\hline & Before $Y$ & After $Y$ & $\begin{array}{l}\text { Turbidity } \\
\text { (NTU) }\end{array}$ & COD & BOD & Sulphide & TKN & AN \\
\hline 1 & 2 & 3 & 4 & 5 & 6 & 7 & 8 & 9 \\
\hline $\begin{array}{c}\text { ATE }+\gamma \\
\text { (Without reagent) }\end{array}$ & 7.8 & 8 & 55 & 29 & 45 & 27 & 8 & 6 \\
\hline $\begin{array}{c}\text { ATE }+200 \mathrm{mg} / \mathrm{L} \mathrm{Fe}+5 \mathrm{~mL} / \mathrm{L} \mathrm{H}_{2} \mathrm{O}_{2} \text { (without } \\
\text { v) }\end{array}$ & 3.25 & 3 & 100 & 35 & 59 & 81 & 12 & 8 \\
\hline$A T E+20 \mathrm{mg} / \mathrm{L} \mathrm{Fe}+5 \mathrm{~mL} / \mathrm{L} \mathrm{H}_{2} \mathrm{O}_{2}+\mathrm{\gamma}$ & 3.75 & 3.5 & 100 & 41 & 57 & 52 & 16 & 8 \\
\hline $\mathrm{ATE}+80 \mathrm{mg} / \mathrm{LFe}+5 \mathrm{~mL} / \mathrm{L} \mathrm{H}_{2} \mathrm{O}_{2}+\gamma$ & 3 & 2.9 & 100 & 54 & 80 & 64 & 18 & 9 \\
\hline $\mathrm{ATE}+140 \mathrm{mg} / \mathrm{L} \mathrm{Fe}+5 \mathrm{~mL} / \mathrm{L} \mathrm{H}_{2} \mathrm{O}_{2}+\mathrm{y}$ & 3 & 2.9 & 100 & 66 & 81 & 83 & 19 & 9 \\
\hline $\mathrm{ATE}+200 \mathrm{mg} / \mathrm{L} \mathrm{Fe}+5 \mathrm{~mL} / \mathrm{L} \mathrm{H}_{2} \mathrm{O}_{2}+\mathrm{y}$ & 2.7 & 2.6 & 100 & 77 & 96 & 95 & 19 & 10 \\
\hline$A T E+300 \mathrm{mg} / \mathrm{L} \mathrm{Fe}+5 \mathrm{~mL} / \mathrm{L} \mathrm{H}_{2} \mathrm{O}_{2}+\mathrm{y}$ & 2.6 & 2.5 & 100 & 76 & 95 & 94 & 19 & 10 \\
\hline $\mathrm{ATE}+400 \mathrm{mg} / \mathrm{L} \mathrm{Fe}+5 \mathrm{~mL} / \mathrm{L} \mathrm{H}_{2} \mathrm{O}_{2}+\mathrm{y}$ & 2.6 & 2.5 & 100 & 77 & 96 & 92 & 19 & 10 \\
\hline
\end{tabular}

\section{Table 6}

Effect of $\mathrm{pH}$ and Fenton's reagent on radiation treatment of ATE

\begin{tabular}{c|c|c|c|c|c}
\hline \multirow{2}{*}{$\begin{array}{c}\mathrm{pH} \\
\text { before }\end{array}$} & \multirow{2}{*}{$\mathrm{pH}$ after } & \multicolumn{4}{|c}{ Percentage removal } \\
\cline { 3 - 6 } & 2 & Turbidity (NTU) & COD & BOD & Sulphide \\
\hline 1 & 2 & 3 & 4 & 86 & 100 \\
\hline 2.5 & 2.3 & 97 & 70 & 88 & 100 \\
\hline 3 & 4.5 & 97 & 72 & 76 & 99 \\
\hline 5 & 7.4 & 63 & 68 & 74 & 95 \\
\hline 7 & 8 & 98 & 23 & 75 & 77 \\
\hline
\end{tabular}

Previous studies using Fenton's reagent showed that $\mathrm{pH}$ near 3 was optimum for Fenton oxidation (Rivas et al., 2001). At higher $\mathrm{pH}$, the ferric ions form $\mathrm{Fe}(\mathrm{OH})_{3}$, which has a low activity and does not react with hydrogen peroxide ${ }^{31}$

$$
\begin{array}{ll}
\mathrm{Fe}^{+2}+\mathrm{H}_{2} \mathrm{O}_{2} & \rightarrow \mathrm{Fe}^{+3}+\mathrm{OH}^{*}+\mathrm{OH} \\
2 \mathrm{Fe}^{+2}+\mathrm{H}_{2} \mathrm{O}_{2}+2 \mathrm{H}^{+} & \rightarrow 2 \mathrm{Fe}^{+3+} 2 \mathrm{H}_{2} \mathrm{O}
\end{array}
$$

The $\mathrm{pH}$ value influenced the generation of ${ }^{*} \mathrm{OH}$ radicals and, thus, increased the oxidation efficiency. The precipitation of iron occurs as its hydroxide reduces the availability of $\mathrm{Fe}^{+2}$ and, hence, oxidation transmission (Faust \& Hoigne, 1990, Walling, 1975). The need of $\mathrm{H}^{+}$ ion to decompose $\mathrm{H}_{2} \mathrm{O}_{2}$ is evident from Eq. 6 indicating the necessity for an acidic environment to produce the maximum amount of hydroxyl radicals. 


\section{Biochemical analysis of the radiated effluent}

Biochemical analysis of raw and irradiated wastewater was done by estimating the change in the concentrations of soluble protein, phenols, total and reducing sugars and free amino acids. The soluble protein concentration of raw effluent (RE) was $865 \mathrm{mg} / \mathrm{L}$. Removal efficiency for soluble protein increased from $38.8 \%$ to $47 \%$ as the dose of radiation increased from 2.5 kGy to 50 kGy (Table 7).

Addition of Fenton's reagent alone removed $36.3 \%$ of soluble protein. However, gamma radiation of $2.5 \mathrm{kGy}$ in the presence of Fenton's reagent removed $87 \%$ of soluble protein. In the case of phenol, the maximum removal efficiency for a radiation dose of $2.5 \mathrm{kGy}$ was $25 \%$. As the dose of radiation increased from $2.5 \mathrm{kGy}$ to $50 \mathrm{kGy}$, an unusual increase in the concentration of phenol than the original one was observed. It is reported that the first step in the phenol decomposition by radiolysis and photo catalysis is oxidation of phenol forming various aromatic intermediates, such as hydroquinone, catechol, pyrogallol and hydroxyhydroquinone (Hashimoto et al., 1979). The hydroxyl radicals produced during radiolysis might have combined with some of the organic molecules producing phenols. However, in the presence of Fenton's reagent alone and a combination of Fenton's reagent and gamma radiation, phenol removal efficiency was $43 \%$ and $48 \%$, respectively.

Gamma radiation could remove $36.5 \%$ to $67.6 \%$ of total sugar when the dose of radiation increased from $2.5 \mathrm{kGy}$ to $50 \mathrm{kGy}$. Nevertheless, the presence of Fenton's reagent and gamma radiation increased the concentration of total sugar from $1,250 \mathrm{mg} / \mathrm{L}$ to $1,567 \mathrm{mg} / \mathrm{L}$. Estimation of reducing sugar and non-reducing sugar also showed unusual values by the simultaneous effect of Fenton's reagent and gamma radiation. This may be due to the decomposition of big organic molecules to small sugar molecules in the presence of Fenton's reagent and gamma radiation.

\section{Table 7}

Results of biochemical analysis

\begin{tabular}{|c|c|c|c|c|c|c|c|}
\hline No & Sample details ( $\gamma$ in $k G y)$ & Soluble protein & Phenol & Total sugar & Reducing sugar & Non-reducing sugar & Free amino acid \\
\hline 1 & 2 & 3 & 4 & 5 & 6 & 7 & 8 \\
\hline 1 & RE & 865 & 586 & 1,250 & 1,095 & 155 & 15,952 \\
\hline 2 & $\mathrm{RE}+2.5 \mathrm{y}$ & 529 & 440 & 793 & 666 & 127 & 11,633 \\
\hline 3 & $R E+50 y$ & 458 & 710 & 405 & 317 & 88 & 14,929 \\
\hline 4 & $\mathrm{RE}+\mathrm{FR}$ & 551 & 335 & 456 & 267 & 189 & 20,082 \\
\hline 5 & $R E+F R+2.5 y$ & 110 & 307 & 1,567 & 2,912 & 203 & 17,556 \\
\hline 6 & ATE & 289 & 45 & 56 & 36 & 20 & 5,779 \\
\hline 7 & $\mathrm{ATE}+2.5 \mathrm{\gamma}$ & nil & 52 & nil & nil & nil & 7,726 \\
\hline 8 & ATE $+3.5 \mathrm{y}$ & nil & 60 & nil & nil & nil & 5,145 \\
\hline 9 & $\mathrm{ATE}+\mathrm{FR}$ & nil & 22 & nil & nil & nil & 5,650 \\
\hline 10 & $\mathrm{ATE}+\mathrm{FR}+2.5 \mathrm{y}$ & nil & 27 & nil & nil & nil & 6,442 \\
\hline 11 & $A T E+F R+5 Y$ & nil & 27 & nil & nil & nil & 6,123 \\
\hline
\end{tabular}

Abbreviations used: RE - raw effluent; ATE - anaerobically treated effluent; $ү$ - gamma radiation; FR - Fenton's reagent. All values are expressed in $\mathrm{mg} / \mathrm{L}$ 
The initial concentration of free amino acids was $15,952 \mathrm{mg} / \mathrm{L}$. For a radiation dose of $2.5 \mathrm{kGy}, 27 \%$ removal was possible. As the radiation dose increased further from $2.5 \mathrm{kG}$ y to $50 \mathrm{kGy}$, free amino acid removal decreased to $6.4 \%$. However, the addition of Fenton's reagent alone and with gamma radiation resulted in an increase in the concentration of free amino acids to $20,082 \mathrm{mg} / \mathrm{L}$ and $17,556 \mathrm{mg} / \mathrm{L}$, respectively. An increase in free amino acids concentration may be due to the decomposition of proteins into individual amino acids in the presence of Fenton's reagent and gamma radiation.

Soluble protein was completely removed when anaerobically treated effluent was subjected to radiation at a dose of $2.5 \mathrm{kGy}$ in the presence of Fenton's reagent. Phenol concentration was found to increase from $45 \mathrm{mg} / \mathrm{L}$ to $52 \mathrm{mg} / \mathrm{L}$ and $60 \mathrm{mg} / \mathrm{L}$ for the gamma radiation dose of $2.5 \mathrm{kGy}$ and $3.5 \mathrm{kGy}$. However, when treated with Fenton's reagent, phenol concentration decreased by $51 \%$ and the combined effect of Fenton's reagent and gamma radiation removed only $40 \%$ of phenol. Almost complete removal of total sugar as well as reducing and non-reducing sugars was possible when anaerobically treated effluent was subjected to irradiation. Estimation of free amino acid showed an increase from $5,779 \mathrm{mg} / \mathrm{L}$ to $7,726 \mathrm{mg} / \mathrm{L}$ when anaerobically treated effluent was subjected to a radiation dose of $2.5 \mathrm{kGy}$. This may be due to the complete decomposition of proteins leading to the formation of amino acids. When the dose was increased to $3.5 \mathrm{kGy}$, amino acid content decreased from 5,779 to 5,145. Again, its concentration increased to $6,442 \mathrm{mg} / \mathrm{L}$ and $6,123 \mathrm{mg} / \mathrm{L}$, respectively, when treated with Fenton's reagent and a combination of Fenton's reagent with gamma radiation. These changes may be due to the formation of radicals and the cleavage of carbon-carbon, carbon-hydrogen, carbon-oxygen and carbon-nitrogen bonds under high-energy radiation.

\section{Microbiological analysis of gamma irradiated effluent}

The total bacterial count of raw as well as irradiated effluent was found out by culturing the samples. The results are given in Table 8. Gamma irradiation having

\section{Table 8}

Results of bacteriological analysis

\begin{tabular}{|c|c|c|}
\hline No & Sample ( $\gamma$ in kGy) & Total bacteria (cfu/mL) \\
\hline 1 & 2 & 3 \\
\hline 1 & RE & $27 \times 10^{4}$ \\
\hline 2 & $\mathrm{RE}+\mathrm{FR}$ & $2 \times 10^{3}$ \\
\hline 3 & $\mathrm{RE}+\mathrm{FR}+2.5 \mathrm{y}$ & nil \\
\hline 4 & $R E+2.5 \gamma$ & nil \\
\hline 5 & ATE & $19 \times 10^{5}$ \\
\hline 6 & ATE $+0.5 \gamma$ & $13 \times 10^{4}$ \\
\hline 7 & $\mathrm{ATE}+1 \gamma$ & $6 \times 10^{4}$ \\
\hline 8 & ATE $+1.5 \gamma$ & $23 \times 10^{3}$ \\
\hline 9 & $\mathrm{ATE}+2 \mathrm{y}$ & $60 \times 10^{2}$ \\
\hline 10 & ATE $+2.5 \gamma$ & $46 \times 10^{2}$ \\
\hline 11 & $A T E+3 y$ & $30 \times 10^{2}$ \\
\hline 12 & ATE $+3.5 \gamma$ & $18 \times 10^{2}$ \\
\hline 13 & ATE + FR & $4 \times 10^{4}$ \\
\hline 14 & ATE + FR + $2.5 y$ & $2 \times 10^{2}$ \\
\hline 15 & $A T E+F R+5 \gamma$ & $1 \times 10$ \\
\hline 16 & $\mathrm{ATE}+\mathrm{FR}+10 \mathrm{y}$ & nil \\
\hline
\end{tabular}

Abbreviations used: RE - raw effluent; ATE - anaerobically treated effluent; $Y$ - gamma radiation; FR - Fenton's reagent. All values are expressed in $\mathrm{mg} / \mathrm{L}$

a dose of $2.5 \mathrm{kGy}$ in the presence or absence of Fenton's reagent completely removed total bacterial population of raw effluent.

Anaerobically treated effluent when subjected to gamma irradiation having a dose of $2.5 \mathrm{kGy}$ in the presence or absence of Fenton's reagent did not remove total bacteria completely. The radiation dose of $5 \mathrm{kGy}$ to $10 \mathrm{kGy}$ in the presence of Fenton's reagent was needed to remove bacteria completely from the anaerobically treated effluent. 


\section{Conclusion}

The gamma radiation dose of $2.5 \mathrm{kGy}$ could be taken as the optimum dose of radiation to treat raw skim serum wastewater.

2 For effective pollutant removal along with the optimum gamma radiation dose, $200 \mathrm{mg} / \mathrm{L}$ of iron and $10 \mathrm{~mL} / \mathrm{L}$ of $\mathrm{H}_{2} \mathrm{O}_{2}$ could be taken as the optimum concentration of iron and $\mathrm{H}_{2} \mathrm{O}_{2}$ in Fenton's reagent. Phosphate removal efficiency was found to increase as the iron concentration in Fenton's reagent increased to $400 \mathrm{mg} / \mathrm{L}$.

3 The effect of irradiation was more prominent in the presence of Fenton's reagent. $\mathrm{pH}$ around 7 could be taken as the optimum $\mathrm{pH}$ to treat raw effluent using gamma radiation, but $\mathrm{pH}$ around 3 was most effective for gamma irradiation along with Fenton's reagent.

4 Anaerobically treated effluent could be more effectively treated using gamma radiation and Fenton's reagent. Sulphides present in the anaerobically treated effluent could be completely removed when irradiated in the presence of Fenton's reagent.

5 Biochemical analysis of the radiated effluent (raw) showed that $87 \%$ of soluble protein could be re-

\section{References}

American Public Health Association (APHA), American Water Works Association (AWWA) and Water Environment Federation (WEF). 1995. "Standard methods for the examination of water and wastewater", 19th Ed. A.D. Eaton, L.S. Clescari, A.E. Greenberg. Eds. APHA. Washington, D.C.

Basfar A.A, and Rehim F.A. 2002. Disinfection of wastewater from a Riyadh wastewater treatment plant with ionizing radiation. Radiation Physics and Chemistry, 65(4-5), 527. https://doi. org/10.1016/S0969-806X(02)00346-8

Buxton C.V., Greenstock C.L., Helman W.P., and Ross A.B. 1988. Critical review of rate constants for reactions of hydrated electrons, hydrogen atoms and hydroxyl radicals in aqueous solution. J. Phy.Chem. Ref. Data., 17, 513. https://doi. org/10.1063/1.555805

Farooq S., Kurucz C.N., Waite T.D.,and Cooper W.J. 1993. Disinfection of wastewaters - high energy electron vs gam- moved for a dose of $2.5 \mathrm{kGy}$ in the presence of Fenton's reagent. In the presence of Fenton's reagent and gamma radiation, $48 \%$ of phenol was removed. For anaerobically treated effluent subjected to the gamma radiation dose of $2.5 \mathrm{kGy}$, soluble protein was completely removed. With Fenton's reagent, phenol concentration could be reduced by $51 \%$, and almost complete removal of total sugar as well as reducing and non-reducing sugars was achieved.

6 The gamma radiation dose of $2.5 \mathrm{kGy}$, irrespective of the presence of Fenton's reagent, could completely remove total bacterial population of raw effluent. In the case of anaerobically treated effluent, the addition of Fenton's reagent in combination with a radiation dose of $5 \mathrm{kGy}$ to $10 \mathrm{kGy}$ was needed to remove bacteria completely.

\section{Acknowledgement}

The authors wish to thank sincerely the Rubber Research Institute of India for providing necessary facilities for carrying out the work. ma-irradiation. Water Research., 27(7), 1177. https://doi. org/10.1016/0043-1354(93)90009-7

Faust B.C, and Hoigne J.1990. Photolysis of Fe(III) - Hydroxy complexes as sources of $\mathrm{OH}$ radicals in clouds, fog and rain., Atmos. Environ.,24(1), 79-89. https://doi.org/10.1016/09601686(90)90443-Q

Gautam S., Shah M.R., Sabharwal S., and Sharma A. 2005. Gamma irradiation of municipal sludge for safe disposal and agricultural use. Water Environ Res., 77(5), 472. https://doi. org/10.2175/106143005X67386

Getoff N. 1996. Radiation - induced degradation of water pollutants - state of the art., Radiation Physics and Chemistry, 47(4), 581. https://doi.org/10.1016/0969-806X(95)00059-7

Hashimoto S., Miyata T., Washino M., and W. Kawakami W.1979. A liquid chromatographic study on the radiolysis of phenol in 
aqueous solution. Environ. Sci. Technol., 13, 71. https://doi. org/10.1021/es60149a008

John E.T., and E.R. Blatchley E.R III. 1999. Gamma irradiation for inactivation of C.Parvum, E.Coli and Coliphage MS-2., Water Research, 33(9), 2053.

Jung J., Yoon J.H.,Chung H.H., and Lee M.J. 2002. Radiation treatment of wastewater from a sewage treatment plant. Radiation Physics and Chemistry, 65(4), 533. https://doi. org/10.1016/S0969-806X(02)00347-X

Jung J., Yoon J.H.,Chung H.H.,and Lee M.J. 2004. A pilot plant study of reclamation of sewage effluent by radiation treatment. Journal of Radio analytical and Nuclear Chemistry., 260 (1), 49. https://doi.org/10.1023/B:JRNC.0000027060.18416.08

Kimura A., Taguchi M., Arai H., Hiratsuka H., Namba H., and Kojima T., 2004. Radiation - induced decomposition of trace amounts of $17 \beta$ - estradiol in water. Radiation Physics and Chemistry, 69(4), 295-301. https://doi.org/10.1016/S0969806X(03)00470-5

Kos L., and Perkowski J., 2003. Decolouration of real textile wastewater with advanced oxidation processes. Fibres \& Textiles in Eastern Europe, 11, 4(43), 81-85.

Kumaran M.G. 1987. Treatment and disposal of rubber effluent. Rubb. Board Bull., 24, 1.

Lowry O.H, Rosebrough N.J., A.L. Farr A.L., and Randall R.J. 1951. Protein measurement with the folin phenol reagent. Journal of Biological Chemistry, 193, 265.

Meeroff D.E., Waite T.D., Kazumi J., and Kurucz C.N., Radiation-assisted process enhancement in wastewater treatment. 2004. J. Envir., Engrg. 130(2), 155. https://doi.org/10.1061/ (ASCE)0733-9372(2004)130:2(155)

Metcalf, and Eddy, Inc. 2003. Wastewater Engineering treatment and reuse. 4th Ed. Tata McGraw-Hill, New Delhi.

Moore S., and Stein W.M. 1948. Photometric ninhydrin method for use in the chromatography of amino acids., Journal of Biological Chemistry, 176, 367.

Nelson G.A. 1944. A photometric adaptation of the Somogyi method for the determination of glucose. Journal of Biological Chemistry, 153, 375.
Perkowski J., and Kos L. 2003. Decolouration of model dyehouse wastewater with advanced oxidation processes. Fibres \& Textiles in Eastern Europe, 11 (3), 42.

Pikaev A.K. 2001. Mechanism of radiation purification of polluted water and wastewater. Water Sci Technol., 44 (5), 131.

Pramer D., and Schmidt E.L. 1965. Experimental soil microbiology. Burges Publishing Co, Minneapolis, Minnesota.

Rice R.G. 1997. Applications of ozone for industrial wastewater treatment - A review. Ozone Science Engineering, 18, 477-515. https://doi.org/10.1080/01919512.1997.10382859

Rivas, F.J, Beltran, F.J, Gimeno, G, and Frades, T. 2001, Treatment of olive oil mill wastewater by Fenton's reagent, J. Agric. Food Chem., 49(4), 1873-1880. https://doi.org/10.1021/ jf001223b

Scott Jr. T.A., and Melvin E.H. 1953. Determination of dextran with anthrone. Analytical Chemistry, 25, 1656. https://doi. org/10.1021/ac60083a023

Swain T., and Hills W.E. 1959. The phenolic constituents of Prunus domestica. Journal of Science and Food and Agriculture, 10, 63-68. https://doi.org/10.1002/jsfa.2740100110

Thomas F.C., Ouwerkerk T., and McKercher P. 1982. Inactivation by gamma irradiation of animal viruses in simulated laboratory effluent. Applied. Environ. Microbiol., 43(5), 1051-1056.

Waite T.D., Kruger P., Bryan E., and Swinwood J.F. 1992. Irradiation treatnt of water and waste. Proceedings of the symposium on Application of isotopes and tradition in conservation of the Environment, Karlsruhe, 143-152.

Walling C. 1975. Fenton's reagent revisited., Accts. of Chem. Research, 8, 125. https://doi.org/10.1021/ar50088a003

Walling C., and Kato S. 1971. Oxidation of alcohols by Fenton's reagent. Effect of copper ion., J. Am. Chem. Soc., 92, 4275. https://doi.org/10.1021/ja00746a031

Wang T., Waite T.D., Kurucz C., and Cooper W.J. 1994. Oxidant reduction and biodegradability improvement of paper mill effluent by irradiation. Water Research, 28(1), 237. https://doi. org/10.1016/0043-1354(94)90139-2

G. C. White G.C. 1978. Disinfection of wastewater and water for reuse. Van Nostrand Reinhold Company, New York. 


\section{Natūralaus kaučiuko latekso centrifugavimo metu susidariusių nuotekų apdorojimas spinduliuote}

\section{Vimalamma T Abraomas}

Chemijos katedra, Šventojo Stepono koledžas, Ušavūras, Kerala, Indija

\section{G. Madhu}

Inžinerijos mokykla, Kochino mokslo ir technologiju universitetas, Kočinas, Indija

\section{N. Radhakrishnan Nair, John Britto}

Gumos tyrimų institutas Indijoje, Kottayam, Kerala, Indija

Natūralaus kaučiuko latekso centrifugavimo proceso metu susidariusios serumo nuotekos yra labai teršiamos. Anaerobiniu būdu išvalytos nuotekos taip pat buvo apdorotos ir gama spinduliuote. Tokiam nuoteku apdorojimui buvo taikomi skirtingi Fenton reagento ir skirtingu doziu gama spinduliuotes deriniai. Nuoteku išvalymo veiksmingumas buvo jvertintas pagal pH, drumstumą, chemini deguonies poreiki, biochemini deguonies poreikị, bendrą Kjeldahlio azotą, amoniakini azotą, bendras kietas medžiagas, ištirpusias kietas medžiagas ir sulfidą. Biocheminių sudedamuju dalių koncentracijos pokyčiai ir bendro bakteriju populiacijos skaičiavimai buvo naudojami nuoteku išvalymo efektyvumui jvertinti. Anaerobiniu būdu valomos nuotekos gali būti veiksmingiau apdorojamos gama spinduliuote su Fentono reagentu. Rezultatai parodè, kad daugelis biocheminių sudedamuju dalių ir bakteriju populiaciju buvo visiškai pašalintos iš anaerobiniu būdu apdorotų nuotekų šiuo metodu.

Raktiniai žodžiai: gama spinduliuotè, apšvitinimas, gumos latekso centrifugavimas, nuoteku valymas, Fentono reagentas. 